森 岡進** 梅園 昭 巳**

\title{
On the Pitting Corrosion Resistance of Titanium
}

Susumu Morioka and Akimi Umezono

The anodic behaviour of the pure titanium in acid, neutral, and alkaline solutions was studied both in the presence and absence of halogen ions. The polarization curves showed that $\mathrm{Cl}^{-}$ion does not discharge at the titanium anode, showing a very high discharge overvoltage on titanium, and so does not prevent the passivation of titanium. The effect of halogen ion on the passivation of anode metal and the pitting corrosion resistivity of titanium were discussed.

\section{1. 緒言}

チタンは酸化作用によって不働態化しやすく，一般に 耐食性がすぐれ不銹鋼に似ているが，海水中などで点食 を生じないことは不銹鋼よりもすぐれている。しかしチ タンが点食に強い理由についてはっきり述べたものを見 ない。ハロゲンイオンを含む酸性, 中性およびアルカリ 性溶液中でチタンの陽極分極の様子を調べた実験結果に 基づいてこの問題を考えてみよう。

\section{2. 実 験 結 果}

（1）水中および硫酸中の自然電丞電位

順序として水中の自然電極電位の時間的变化を測定す ると第 1 図のごとくになる。チタンを脱脂, 研摩して直

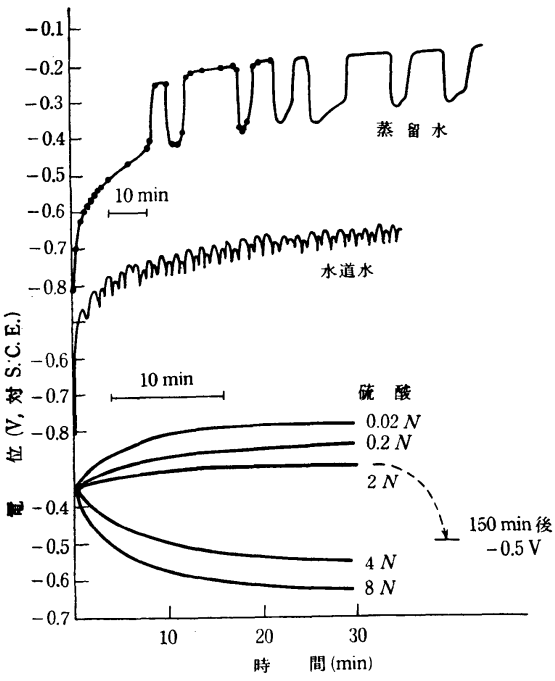

第 1 図蒸留水, 水道水および硫酸中に おけるチタンの電位-時間曲線
ちに水中

に浸漬し

てとの瞬

間から電

位を測定

した。

チタン

は活性な

金属であ

るから水

と反応し

$\tau(1)$ 式

のごとく

チタニィ

ルイオン

$\mathrm{TiO}^{++}$と

なり,そ

の水酸化

* 学振腐蝕防止第 97 委員会月例会議（昭 34.4.16）報告

** 東北大学工学部金属工学科

物の溶解度積は小さいわら百らちに（2）式のごとく水酸化 物になり，この皮膜のために電位は時間と共に貴になる。

$$
\begin{aligned}
& \mathrm{Ti}+\mathrm{H}_{2} \mathrm{O} \longrightarrow \mathrm{TiO}^{++}+2 \mathrm{H}^{+}+4 \mathrm{e}^{-} \ldots \ldots \ldots \ldots \ldots \ldots . . . . \\
& \mathrm{TiO}^{++}+2 \mathrm{OH}^{-} \longrightarrow \mathrm{TiO}(\mathrm{OH})_{2}\left(=\mathrm{TiO}_{2} \cdot \mathrm{H}_{2} \mathrm{O}\right)
\end{aligned}
$$

電気伝導度のきわめて小さい蒸留水中では週期的変化 をしながら次第に貴になり，水道水のように電気伝導度 が少し大きくなると週期的変化の週期が小さくなり，更 に電気伝導度が大きくなると硫酸中のように週期的変化 はしなくなる。硫酸が波くなると $\mathrm{TiO}(\mathrm{OH})_{2}$ の沈殿が生 ごないし，大気中で生じていた酸化物皮膜も溶解するた めに時間と共に早になる。 $2 \mathrm{~N}-\mathrm{H}_{2} \mathrm{SO}_{4}$ 中ではとの中間で はじめは少し貴になるが長時間後には卑になる。

\section{（2）硫酸水溶液中の陽極分極}

第 1 図の硫酸浸清 $30 \mathrm{~min}$ の状態から陽極分極をする と第 2 図の分極曲線が得られる。0.02 N および $0.2 N$ $\mathrm{H}_{2} \mathrm{SO}_{4}$ のごとく大気中で生じていた酸化物皮膜が溶けな

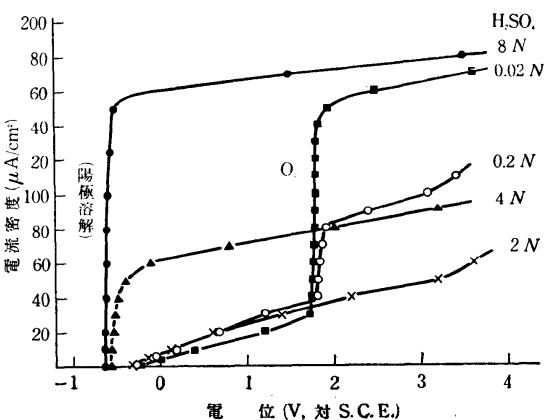

第 2 図硫酸中に括けるチタンの陽 極分極曲線 い溶液中 では, 最 初印加電 圧と共に 分極が進 み, 約 1.8 Vに達す ると酸素 放電によ って電流 が通って 分極ぶ止

る。 $4 \mathrm{~N}$ および $8 \mathrm{~N}-\mathrm{H}_{2} \mathrm{SO}_{4}$ のごとく大気中で生じてい た酸化物皮膜が溶けてしまう溶液中では，最初はチタン の陽極的溶解によって電流が通り，一定の高い電流密度 に達すると溶解が止り酸化物皮膜が止じはじめるため急 
に分極が進む。その途中約 $1.8 \mathrm{~V}$ に達しても酸素放電 を赤さないで分極が進行する。 $2 \mathrm{~N}-\mathrm{H}_{2} \mathrm{SO}_{4}$ 中では両者の 中間で，最初印加電圧と共に分極が進むが，1.8 V に達

\section{しても酸素発生を示さない。}

この結果から大気中で生じたチタンの酸化物皮膜は電 父伝導性があるが，陽極酸化によって生じた酸化物皮膜 は電気伝導性がないことがわかる。 $2 \mathrm{~N}-\mathrm{H}_{2} \mathrm{SO}_{4}$ 中では分 極が進行している間に大父中で生じていた酸化物皮膜が 次第に陽極酸化皮膜に变化し約 $1.8 \mathrm{~V}$ に達したときに は全部変化し終っていることが知られる。

\section{（3）ハロゲンイオンを含む水溶液中の陽極分極}

電解液には次の各溶液を用いた。Xはハロゲンを示す。

(1) $2 \mathrm{~N}-\mathrm{H}_{2} \mathrm{SO}_{4}$ および $2 \mathrm{~N}-\mathrm{H}_{2} \mathrm{SO}_{4}+0.1 \mathrm{~mol} / l \mathrm{KX}$

(2) $0.1 \mathrm{~mol} / l \mathrm{KX}$ の中性水溶液

(3) $N-\mathrm{KOH}$ および $N-\mathrm{KOH}+0.1 \mathrm{~mol} / l \mathrm{KX}$

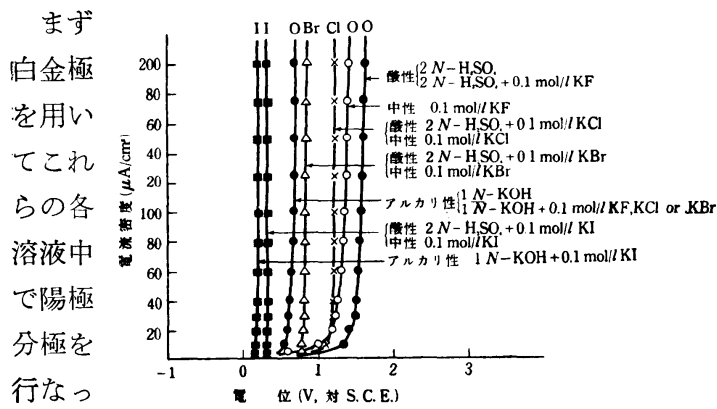

た結果第 3 図 ハロゲンイオンを含む酸性中性及びフ

第 3 ルカリ性溶液中に打ける白金の陽極分極曲線

図のごとくである。すなわちいずれの溶液においても溶 液中に含まれる陰イオンのうち最も低い電位で放電し得 るイオンの放電だけが現われる。

チタン極を用いて陽極分極を行なった場合は少し複雑 であるか ら酸性, 中性, ア ルカリ性 に分けて 示すと第 $4 \sim 6$ 図 のごとく である。

、ずれも 溶液につ けた瞬間 から $1 \mathrm{~m}$ $\mathrm{A} / \mathrm{cm}^{2}$ の 電流密度 で表面酸 化物を 30

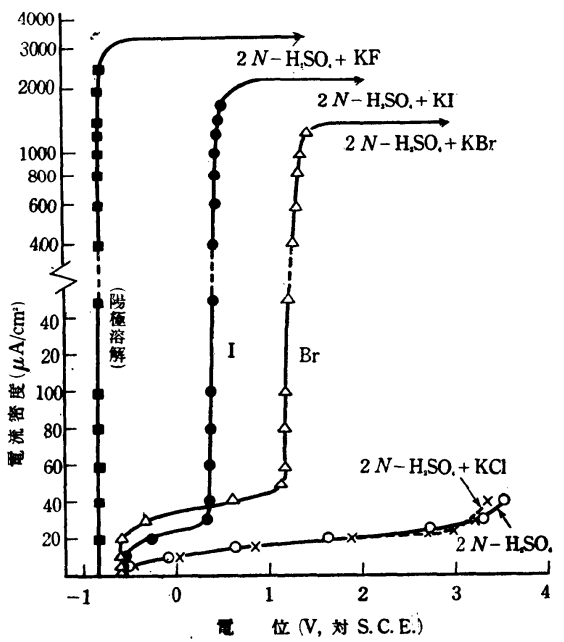

第4图八ロゲン塩 $0.1 \mathrm{~mol} / l$ を含む $2 N$ $\mathrm{H}_{2} \mathrm{SO}_{4}$ 中にお汁るチタンの陽極分極曲線

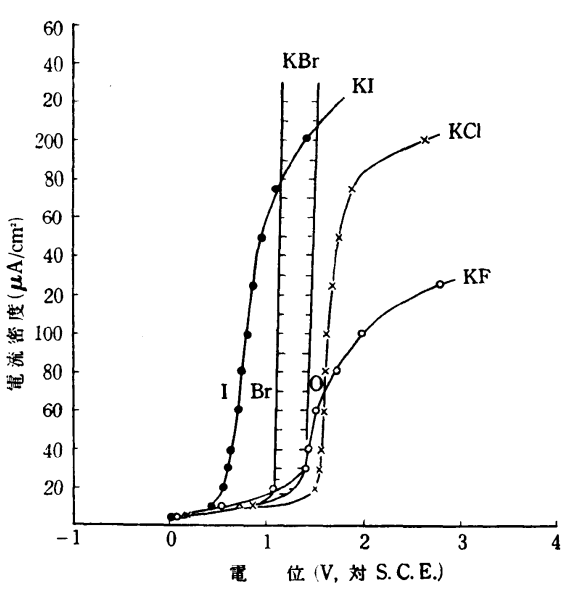

$\min$ 陰極

的に罡元

した後に

隄㥛分極

曲線を求

めた。

酸性溶

液（第 4

図）に扮

ける $2 N$

$\mathrm{H}_{2} \mathrm{SO}_{4}$ 中

0)分極曲

緗は第 2

図に㜔明

第 5 図ハロゲン塩 $0.1 \mathrm{~mol} / l$ の中性水溶

したよう 液中に打けるチタンの陽極分極曲線 に酸素放電を示さない。 $2 \mathrm{~N}-\mathrm{H}_{2} \mathrm{SO}_{4}$ に $\mathrm{KBr}, \mathrm{KI}$ を加 えるとそれぞれ $\mathrm{Br}^{-}$イオン， I- イオンの放電を示すが $\mathrm{KCl}$ を加えても $\mathrm{Cl}^{-}$イオンの放電を示さない。これは 白金極の場合と特に異なる点である。KF を加えた場合 は，弗化水素酸法弱酸であるから未解離の HF を生じ， これによって $\mathrm{TiO}_{2}$ も $\mathrm{Ti}$ も溶ける。ゆえにこの場合だ けは最初チタンの陽極的溶解によって電流が通り約 3 $\mathrm{mA} / \mathrm{cm}^{2}$ て達すると溶解が止えで急に分極が進み，酸 素放電も弗素放電も示さない。

中性溶液（第 5 図）においては， $\mathrm{KF}$ および $\mathrm{KCl}$ 溶 液中ではいずれも 酸素の放電だけを示し，KI 溶液中で は $\mathrm{I}^{-}$イオンの放電を示し, $\mathrm{KBr}$ 溶液中ではチタンの電

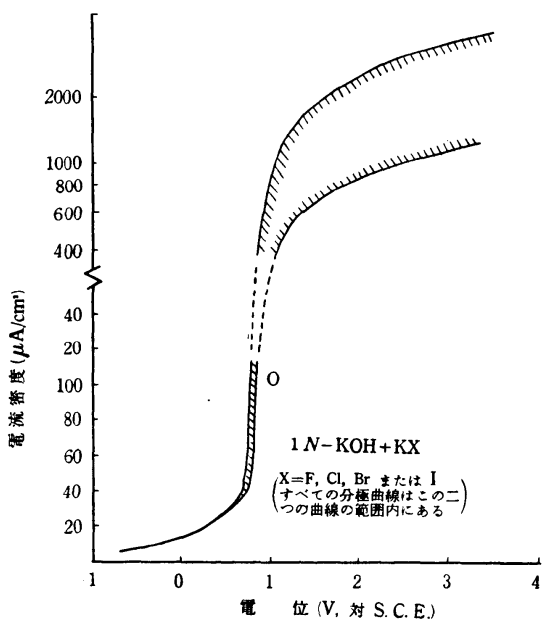

位は酸素 放電電位 と臭素放 電電位と の間を急 速に振動 L, 点食 を生じ, 液中に注 白色コ口 イド状の チタン水 酸化物が 浮遊する

第 6 図 八ロゲン塩 $0.1 \mathrm{~mol} / l$ を含む $N$ - ようにな $\mathrm{KOH}$ 中に拈けるチタンの陽極分極曲線 る。アル カリ性溶液（第 6 図）においてはいずれも酸素の放電だ けを示す。Iーイオンだけはアルカリ性溶液中でも酸素よ り低い電位で放電すべきであるのにその放電は分極曲線 上に認められない。 


\section{3. 考察}

ハロゲンイオンを含む溶液中に打ける陽極分極実駼の 結果をまと放 7 図のごとくになる。すなわち白金 極を用いた之きの各除イオンの放電電位は理論值よりは

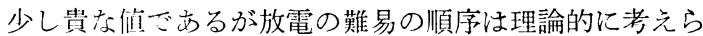
れる順序になっている。ところがチタン極を用いたとき 洛イオンの放電の過電圧が白金極におけるよりも大き くて，それぞれ の放電電位が総 体的に貴になっ ているが，特に 藷しいこと注 $\mathrm{Cl}^{-}$イオン放電 の過電压が非常 に大きくて酸性 および中性溶液 から $\mathrm{Cl}^{-}$イオン の放電を見ない ことである。ま たアルカリ性溶 液から I- イ才 ンの放電を見な いことである。

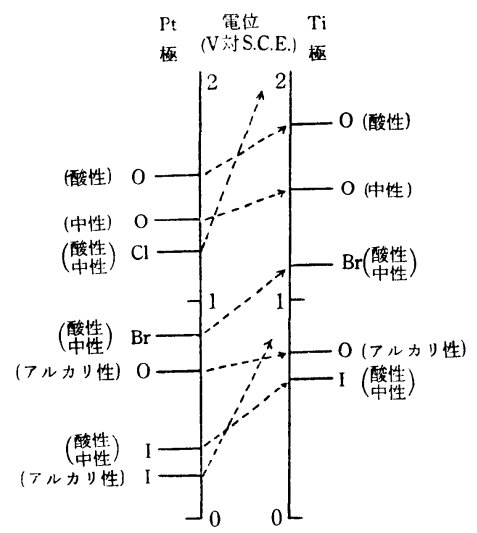

第7図白金極扣よびチタン極に括け る酸素およびハロゲンの放電 析出電位

$\left(100 \mu \mathrm{A} / \mathrm{cm}^{2}\right.$ における電位で比較)

チタン晹極から Cl一 イオンを放電しないことはチタ ソと酸素との視和力が䘏素との親和力よりも著しく強く て $\mathrm{OH}^{-}$イオンあるいは $\mathrm{SO}_{4}=$ イオンの吸着一放電が優 先することを示すものである。不働態化した不銹鋼陽極 においては白金極の場合と同じように酸素よりも $\mathrm{Cl}^{-}$イ オンの放電が容易であり ${ }^{1)}$ ，また不銹鋼は海水などの $\mathrm{Cl}^{-}$ イオンを含も溶液中で点食を生ずることが知られてい る。チタンでも前述のごとく $\mathrm{Br}^{-}$イオンを含も中性溶 液中で汇 $\mathrm{Br}^{-}$イオンの放電が起り点食を生ずる。以上 の関係を考えると，チタン面で $\mathrm{Cl}^{-}$イオンが放電しな いことが $\mathrm{Cl}^{-}$イオンを含も溶液中で点食を生じない原 因である之考えられる。チタン面における $\mathrm{Cl}^{-}$イオンの 放電は非常に高電位であるらしく Hall \& Hackerman ${ }^{2)}$ によれば $10 \mathrm{~V}$ (対 S.C.E.) で点食が生じはじめるとい い，大塚氏 ${ }^{3)}$ によれば塩化力リ水溶液中で 2 枚のチタン の間に電圧をかけると $12 \mathrm{~V}$ になってはじめて陽極に点 食が生じたと報告されている。

八ロゲンイオンは一般に金属の不働態を妨げて点食の 原因になるがまずその理由から考える必要がある。普通 の考え4)では $\mathrm{Cl}^{4}$ イオンは小さいイオンで貫通力が大き いから皮膜の欠陷に侵入して金属を侵し活性化すると説

明しているのであるが，もしてうならばチタンは $\mathrm{Br}^{-}$イ オン溶液中で点食を生ずるのであるからイオンの大きさ の流とんど同じである $\mathrm{Cl}^{-}$イオン溶液中でも点食を生ず る流ずである。ところが $\mathrm{Cl}^{-}$イオン溶液中では点食を生 じないのであるから， $\mathrm{Cl}^{-}$イオンは貫通力が大きい上い う澕え方は誤である。チタン表面で $\mathrm{Br}^{-}$イオンは放電 するが $\mathrm{Cl}^{-}$イオンは放電しないことに点食発生の有無 の原因を求めるべきであろう。今陽極酸化によって不働 態化した金属表面に陰イオンが放電する反応についてま ず考えてみると，たとえば $\mathrm{OH}^{-} \rightarrow \mathrm{OH}+\mathrm{e}^{-}$のごとく， これはェレクトロンを放出する反応である。この遊離さ れたエレクトロンは不働態化によって生じた酸化物皮膜 蓝って金属に達するが，てのエレクトロンの透った道 注電父伝導度の大きい，金属イオンの透り易い一つの欠 陷となって，これを通じて金属イオンが皮膜表面に洼し 易くなる5)。もし酸素を含气除イオンの吸着一放電ならば 欠陷老透って皮膜表面に拡散してきた金属イオンは吸着 陰イオンと結合して酸化物となり，皮膜の生長または皮 朕欠佃の補修をするから不働態は破れない。

ところがハロゲンイオンの吸着一放電の場合には不浴 性塩を造らないから年陷注補修されないでそこに電流が 集中して点食にまで発展する。缉も普通に存在し，乙か も酸素よりも放電し易いハロゲンイオンは $\mathrm{Cl}^{-}$イオン であるが，チタン表面では前述のごとく $\mathrm{Cl}^{-}$イオンは放 電しないために, チタンの場合には $\mathrm{Cl}^{-}$イオンの存在は 点食の原因にならないわけである。チタンが点食に強い というのはこのような理由に基ゔくと考えられる。

\section{4. 要約}

腐食液中の塩素イオンは，金属が活性で腐食している 啰悀には水酸化物のような反応生成物の膠質粒子の凝結 犵溶解度に影響を及ぼすことによって間接に腐食度に 影響を及ぼすが，不働態金属の場合には放電するか否か によって不働態を破るか否かの影響を及ぼす。すなわ方 放電は不働態皮膜に欠陌を生ぜしめるから，不溶性䘏を 造らない㓌イオンが放電するときには点食にまで発展す る。チタンが塩素イオンを含も溶液中で点食を生じない のは，チタンと酸素との親和力が非常に大きいために酸 素の吸着一放電が優先して, 嗑素イオンの吸着一放電を尘 じないからである。

\section{文献}

1) 森岡, 畸山：日本金属学会誌, 18, 643, 647 (1954); 電気化学, 25, 191 (1957).

2) C. D. Hall et al : J. Phys. Chem., 57, 262 (1953)

3) 大塚：防蝕技術, 8, 3 号, 108 頁, 討論椭 (昭和 34 年).

4) たとえば S. C. Britton et al : J. Chem. Soc., 1930, 1781.

5) H. E. Haring : J. Electrochem. Soc., 99, 30 (1952) 